\title{
Temperature Based Agrometeorological Indices for Indian Mustard under Different Growing Environments in Western Haryana, India
}

\author{
Divesh Choudhary", Raj Singh, C.S. Dagar, Anil Kumar and Surender Singh
}

Department of Agricultural Meteorology, Chaudhary Charan Singh Haryana Agricultural University, Hisar-125004, Haryana, India

*Corresponding author

\section{A B S T R A C T}

\begin{tabular}{|l|}
\hline K e y w o r d s \\
Indian mustard, Heat \\
units, Helio-thermal \\
units, Photo \\
temperature, \\
$\begin{array}{l}\text { Nyctotemperature, } \\
\text { Photo-thermal units, } \\
\text { Thermal use efficiency }\end{array}$ \\
\hline Article Info \\
\hline $\begin{array}{l}\text { Accepted: } \\
\text { 10 December } 2017 \\
\text { Available Online: } \\
\text { 10 January } 2018\end{array}$ \\
\hline
\end{tabular}

\section{Introduction}

Mustard is very sensitive to climatic variables due to the determinate characteristics, the variations of weather parameters are very much influence to the phenology and yield attribute and hence, climate change could have significant effect on its physiological activity and production, the main aim of present study to determined thermal regime of mustard crop and its impact on phenology and yield under different growing environment along with varieties performance under sure irrigation facility and other cultural practices, and management, which was followed by the university recommendation during both the rabi season. The decline and/or stagnation in mustard yield causing negative growth rate from 1997 was possibly due to unfavourable monsoon, which created moisture stress (drought and excess rainfall) and rise in temperature (Kumar, 2005). High temperature during early sowing and early crop growth $\left(2^{\text {nd }}\right.$ week of September to first week of November) were lead to poor initial growth and poor plant population. Thus abnormal 
weather condition during early establishment adversely effects the mustard and later on, it sensitivity to cold spell, fog, foggy days, frost, leaf wetting period and intermittent rains during flowering to pod formation stage are all causes for concern in the major mustard producing states of Rajasthan, UP and Haryana. In addition to these adverse effects, considerable yield losses are caused by physiological disorders along with proliferation of aphid pest, white rust, downy mildew and stem rot diseases in India.

Mustard is an important rabi crop grown in Haryana and the state contributes about 10.23 per cent of the total rapeseed-mustard production of the country. Weather and climate greatly influences the mustard productivity in the state as can be gauged from seasonal yield fluctuations (Anonymous 2015). The agricultural production and productivity of any region is being regulated by the prevailing climate of that area through temperature, rainfall, light intensity, radiation, sunshine duration etc. (Goswami et al., 2006) and the temperature is the most pivotal weather parameter which affects the phenology, growth and yield in field crops.

Heat units (HU), photo-thermal unit (PTU), helio-thermal unit (HTU), phototemperature, nyctotemperature and heat use efficiency (HUE) are certain temperature based agrometeorological indices those have frequently been used for assessing crop phenology, growth and yield in field crops. Use of these indices are computed over different growth and development stages of crop rather than calendar dates and thus predictions made based upon the are more accurate (Warthington and Hatchinson, 2005). The HU is used to quantify effect of temperature and describes the timing of different biological process (McMaster and Wilhelm, 1997; Qiao-yan et al., 2012). The winter crops including mustard are highly temperature sensitive and the temperature variability alters the duration of different phenophases (Parya et al., 2010). However, little information is available in literature related to the impact of temperature, day length and bright sunshine hour on mustard yield in the region. The main aim of present study was to determine optimum thermal regimes for mustard crop in form of different temperature based agrometeorological indices and assess impact thereof on phenology and yield of three mustard varieties under different growing environments under semi-arid condition in Haryana.

\section{Materials and Methods}

The present field study was conducted at Research Farm of Department of Agricultural Meteorology, CCSHAU, Hisar $\left(29^{\circ} 10^{\prime} \mathrm{N}\right.$, $75^{\circ} 46^{\prime} \mathrm{E}$ and $215.2 \mathrm{~m}$ amsl) during rabi season 2012-13 and 2013-14.

The experiment was laid out in split plot and consisted of three growing environments imposed through different sowing dates $\left(D_{1}\right.$ : Oct. 10, 2012 and Oct. 21, 2013; $\mathrm{D}_{2}$ : Oct. 25, 2012 and Oct. 30, 2013; and $\mathrm{D}_{3}$ : Nov. 8, 2012 and Nov. 10, 2013) in the main plots and three mustard varieties (V1: RH 30, V2: Laxmi and V3: RH 0749) in sub- plots and replicated four times. The weather data recorded at Agrometeorology Observatory of CCS HAU, and observations on crop phenology, seed and biological yield have been used to compute temperature based agrometeorological indices and establish their relationship with phenology, seed and biological yield of mustard at Hisar. The crop phenology was recorded by visual observation in experimental plots on every alternate day during the crop growing period and the number of days taken for occurrence of different phenophases viz., $\mathrm{P}_{1}$ : Emergence, $\mathrm{P}_{2}$ : four leaf stage, $\mathrm{P}_{3}$ : Early vegetative phase, $\mathrm{P}_{4}$ : $50 \%$ flowering, $\mathrm{P}_{5}: 50 \%$ pod development, 
$\mathrm{P}_{6}$ : Start of seed filling, $\mathrm{P}_{7}$ : End of seed filling, $\mathrm{P}_{8}$ : Physiological maturity.

\section{Temperature based agrometeorological indices}

Cumulative heat units (HU) were determined by summing the daily mean temperature above base temperature $\left(\mathrm{T}_{\mathrm{b}}\right)$, expressed in ${ }^{\circ} \mathrm{C}$ day. For Brassica species, $\mathrm{T}_{\mathrm{b}}$ is considered as $5^{\circ} \mathrm{C}$ following Morrison (1996). This was calculated by using the following formula:

$\mathrm{HU}\left({ }^{\circ} \mathrm{C}\right.$ day $)=\sum_{i}^{j} \frac{\mathrm{Tmax}+\mathrm{Tmin}}{2}-\mathrm{T}_{\mathrm{b}}$

Where,

$\mathrm{T}_{\max }=$ Daily maximum temperature $\left({ }^{\circ} \mathrm{C}\right)$, $\mathrm{T}_{\min }=$ Daily minimum temperature $\left({ }^{\circ} \mathrm{C}\right)$, $\mathrm{T}_{\mathrm{b}}=$ Minimum threshold/base temperature $\left({ }^{\circ} \mathrm{C}\right)$.

Cumulative photo-thermal units (PTU) were determined by multiplying the $\mathrm{HU}$ to the maximum possible sunshine hours, expressed in ${ }^{\circ} \mathrm{C}$ day hours.

PTU $\left({ }^{\circ} \mathrm{C}\right.$ day hours $)=\sum_{i}^{j} \mathrm{HU} \mathrm{x}$ maximum bright sunshine hours

Cumulative helio-thermal unit were (HTU) determined by multiplying the $\mathrm{HU}$ to the actual bright sunshine hours, expressed in ${ }^{\circ} \mathrm{C}$ day hours.

HTU $\left({ }^{\circ} \mathrm{C}\right.$ day hours $)=\sum_{i}^{j} \mathrm{HU} \mathrm{x}$ actual bright sunshine hours

Phototemperature $\left(T_{p}\right)$ can be best defined as the effective light temperature as given below:

$T_{p}=T_{\max }-\frac{1}{4}\left(T_{\max }-T_{\min }\right)_{\text {(iv) }}$

Where, $T_{\max }$ and $T_{\min }$ are the daily maximum and the minimum temperatures in ${ }^{\circ} \mathrm{C}$, respectively. This index is computed cumulatively for the phenological stages and reflects the significance of the mean temperature during daytime (Dalezios et al., 2002).

Like phototemperature, nyctotemperature corresponds to a mean temperature during night, when light levels are limited or nonexistent. This index is expressed (Dalezios et al., 2002) as:

$T_{n}=T_{\min }+\frac{1}{4}\left(T_{\max }-T_{\min }\right)$

Where, $T_{\max }$ and $T_{\min }$ are the daily maximum and minimum temperatures in ${ }^{\circ} \mathrm{C}$, respectively.

The thermal use efficiency was computed to compare the relative performance of different growing environments and mustard varieties at 30 days interval using the following formula:

$\operatorname{TUE}\left(\mathrm{g} / \mathrm{m}^{2}{ }^{\circ} \mathrm{Cday}\right)=\sum_{i}^{j} \frac{\text { Total biological yield }\left(\mathrm{g} / \mathrm{m}^{\mathrm{2}}\right)}{\text { Accumulated heat units }\left({ }^{\mathrm{C} C \text { day }}\right)}$

The coefficient of determination was computed between the observed and simulated values using the following formula:

$\mathrm{R}^{2}=1-\left(\mathrm{SS}_{\text {regression }} / \mathrm{SS}_{\text {total }}\right)($ vii)

Where,

$\mathrm{SS}_{\text {regression }}=$ regression sum of square, $\mathrm{SS}_{\text {total }}=$ total sum of square.

\section{Results and Discussion}

The agrometeorological indices were derived from Agrimet observatory recorded meteorological variables. These indices can be used as a tool for prediction of crop 
phenology, yield and biomass production in crops.

\section{Heat Unit (HU)}

The HU accumulated for occurrence of different phenophases among the treatments during two crop seasons are presented in Figure 1. A peep into Figure 1 revealed that growing environments varied for accumulated HU over different phenophases. Accumulation of $\mathrm{HU}$ to attain crop maturity was higher under $10^{\text {th }}$ Oct sown crop as compared to the other sowing dates and the respective values for three sowing dates were $1582.2,1354.1$ and $1290.5^{\circ} \mathrm{C}$ day in $10^{\text {th }}$ Oct., $25^{\text {th }}$ Oct. and $10^{\text {th }}$ Nov. In 2013-14 crop season the respective values for $22^{\text {nd }}$ Oct., $30^{\text {th }}$ Oct. and $10^{\text {th }}$ Nov. sown crop were $1476.5,1278.2$ and $1148.7^{\circ} \mathrm{C}$ day. In both the seasons the accumulated HU declined with successive delay in sowing and the findings are in conformity with those reported by Roy et al., (2005) and Neogi et al., (2005). The late sown crop accumulated fewer HU during early phenophases than early sown crop due to prevalence of comparatively lower temperature (Srivastava et al., 2011; Renganayaki and Krishnasamy, 2013). Among the varieties, RH $0749\left(\mathrm{~V}_{3}\right)$ accumulated the highest $\mathrm{HU}$ from emergence $\left(\mathrm{P}_{1}\right)$ to physiological maturity $\left(\mathrm{P}_{8}\right)$ in both the years followed by Laxmi $\left(\mathrm{V}_{2}\right)$ and $\mathrm{RH} 30\left(\mathrm{~V}_{1}\right)$. During 2012-13, the HU value for RH 0749 reached to $1557.8^{\circ} \mathrm{C}$ day, whereas, this value was $1449.5^{\circ} \mathrm{C}$ day in $2013-14$ ( $\mathrm{Si}$ and Walton, 2004).

\section{Photo thermal units (PTU)}

The photothermal units (PTU) (a product of HU and maximum possible sunshine) accumulation by mustard crop to attain different phenophases among the treatments in two crop seasons are presented in Figure 2. Among different crop growing environments, mustard crop sown on first date $\left(D_{1}\right)$ accounted for highest PTU at all phenophases followed by crop sown on $\mathrm{D}_{2}$ and $\mathrm{D}_{3}$ dates of sowing in both the crop seasons. The pattern of PTU accumulation among the mustard varieties in respective crop season was similar to the one observed for $\mathrm{HU}$ The PTU accumulation increased from emergence to physiological maturity and highest values were recorded at physiological maturity in all treatments. Similar findings have also been reported by Srivastava et al., (2011).

\section{Helio Thermal Units (HTU)}

The accumulated heliothermal units (HTU) at different phenophases in mustard during two crop seasons are presented in Figure 3. The mustard crop sowed on first date of sowing $\left(D_{1}\right)$ accrued higher heliothermal units over $D_{2}$ and $\mathrm{D}_{3}$ during both the crop seasons. The pattern of HTU accumulation among varieties in both the crop seasons was similar to that of HU and PTU. These findings are in line with those reported earlier by Kumar et al., (2010); Kingra and Kaur (2012) and Neogi et al., (2005). HTU accumulation was higher at all growth phases during 2012-13 as compared to 2013-14 due to availability of higher mean numbers of sunshine hours in this year.

\section{Phototemperature $\quad\left(\mathrm{T}_{\mathrm{p}}\right) \quad$ and nyctotemprature $\left(T_{n}\right)$}

The Accumulated phototemperature $\left(\mathrm{T}_{\mathrm{p}}\right)$ and nyctotemprature $\left(T_{n}\right)$ at different phenophases in mustard during rabi season of 2012-13 and 2013- 14 are depicted in Figure 4 \& 5, respectively. The mustard crop was sown on $\mathrm{D}_{1}$ date of sowing summated higher phototemprature and nyctotemperaure over $\mathrm{D}_{2}$ and $\mathrm{D}_{3}$ during both the crop seasons. Among the varieties, the trend of accumulated $T_{p}$ was similar to the HU irrespectve of treatments and phenophases in both the crop seasons (Dalezios et al., 2002). 
Fig.1 Effect of growing environments and varieties on accumulated heat units $\left({ }^{\circ} \mathrm{C}\right.$ day) requirement to attain various phenophases in mustard during 2012-13 and 2013-14

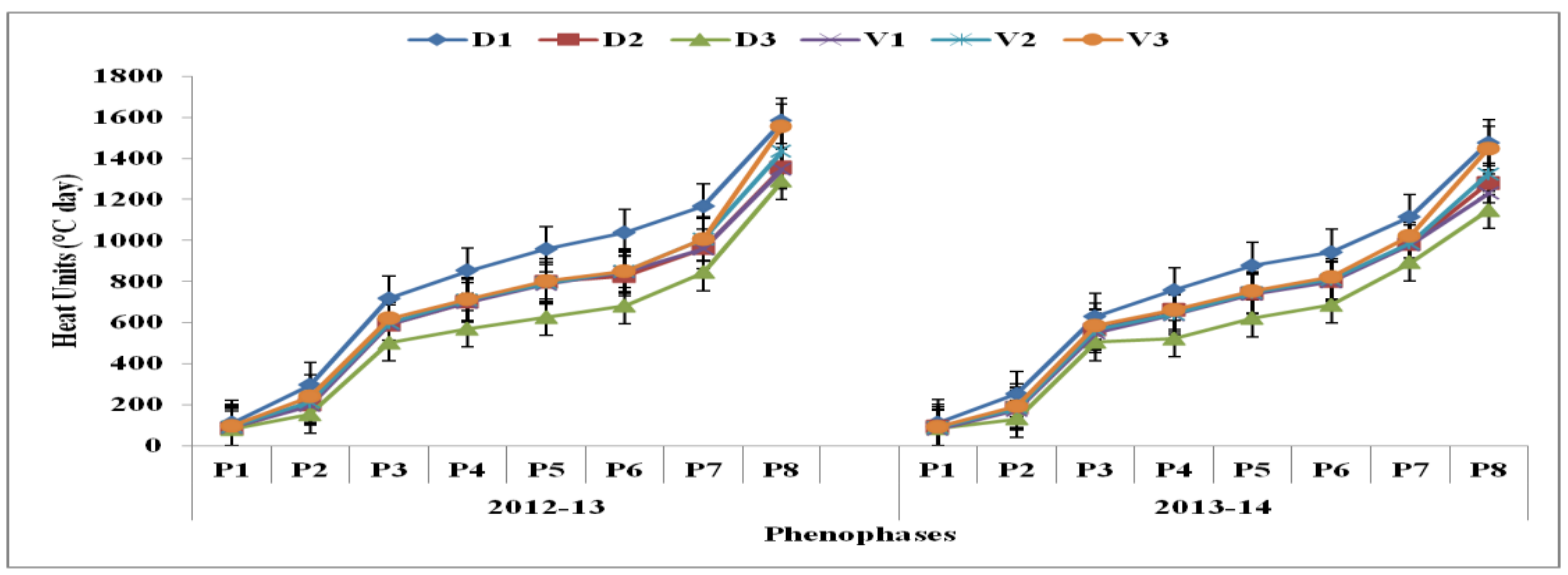

Fig.2 Effect of growing environments and varieties on accumulated photo-thermal units $\left({ }^{\circ} \mathrm{C}\right.$ day hours) requirement to attain various phenophases in mustard during 2012-13 and 2013-14

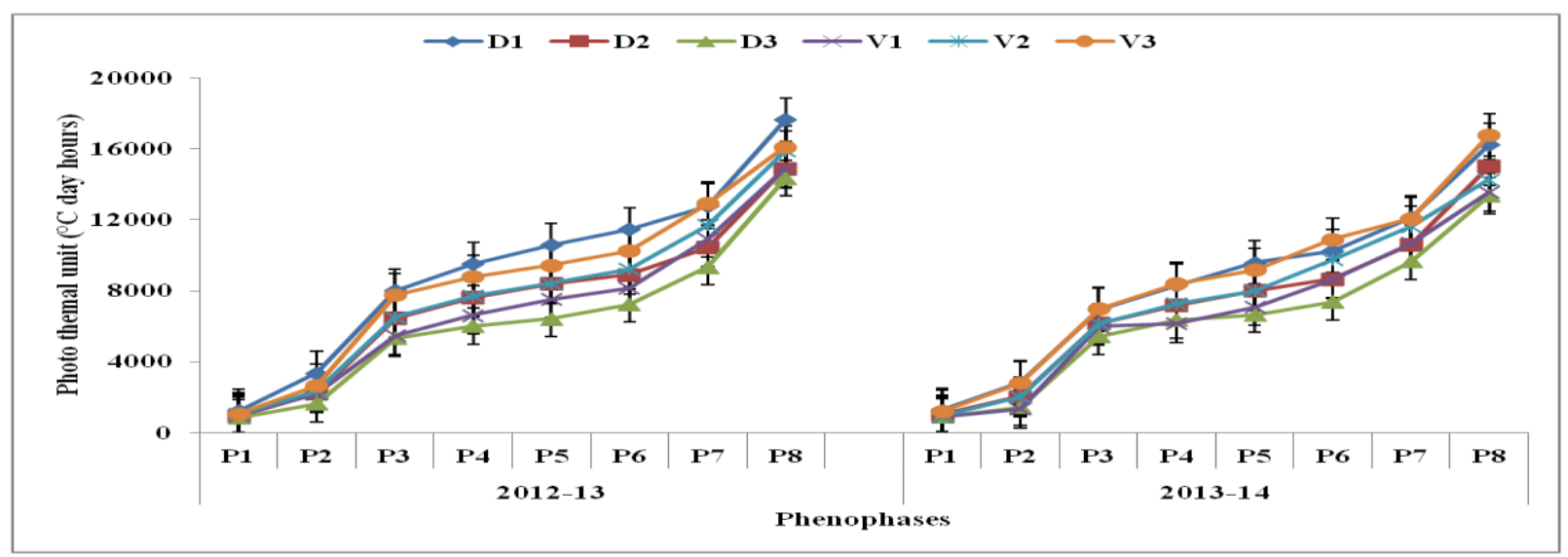

Fig.3 Effect of growing environments and varieties on accumulated helio-thermal units $\left({ }^{\circ} \mathrm{C}\right.$ day hours) requirement to attain various phenophases in mustard during 2012-13 and 2013-14

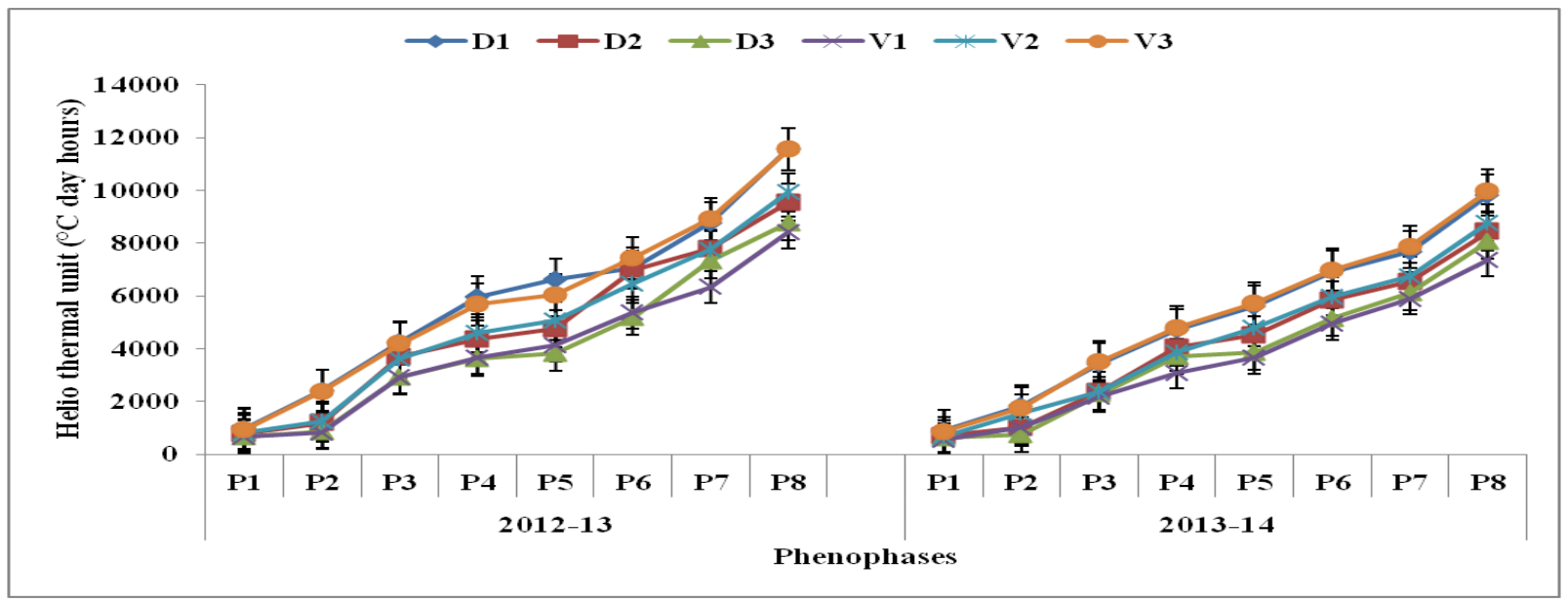


Fig.4 Effect of growing environments and varieties on accumulated phototemperature $\left({ }^{\circ} \mathrm{C}\right.$ day) requirement to attain various phenophases in mustard during 2012-13 and 2013-14

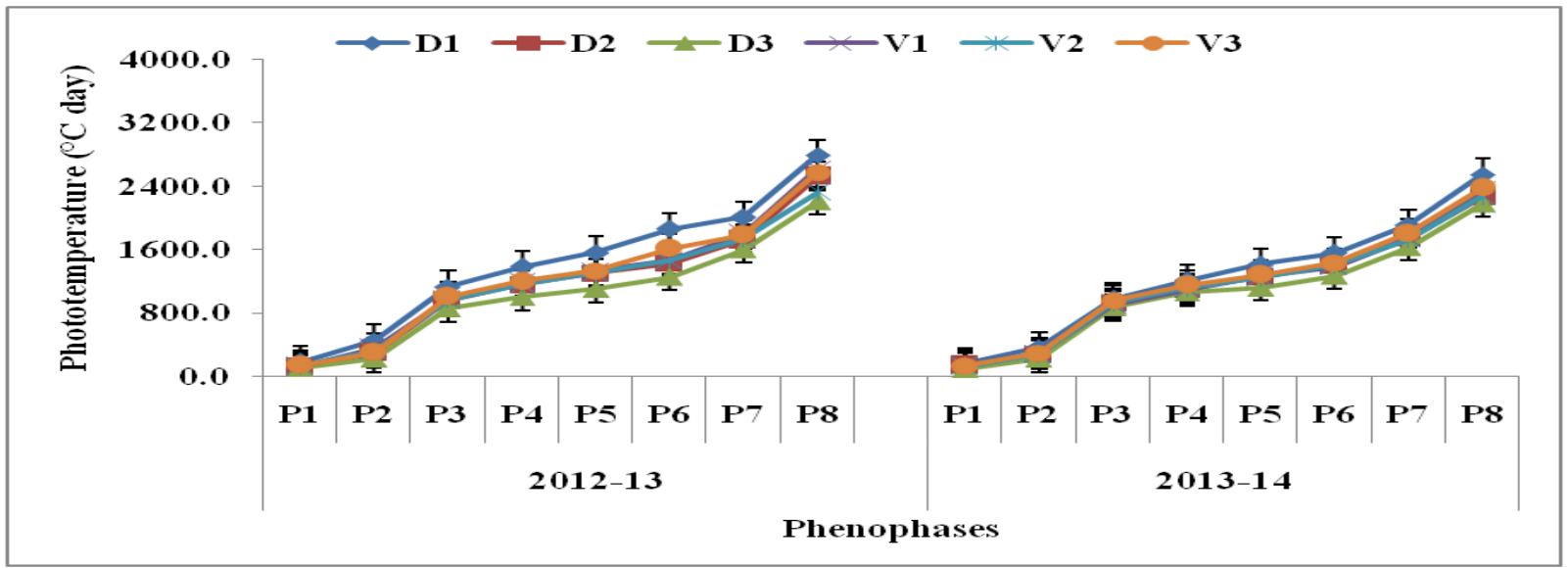

Fig.5 Effect of growing environments and varieties on accumulated nyctotemperature $\left({ }^{\circ} \mathrm{C}\right.$ day) requirement to attain various phenophases in mustard during 2012-13 and 2013-14

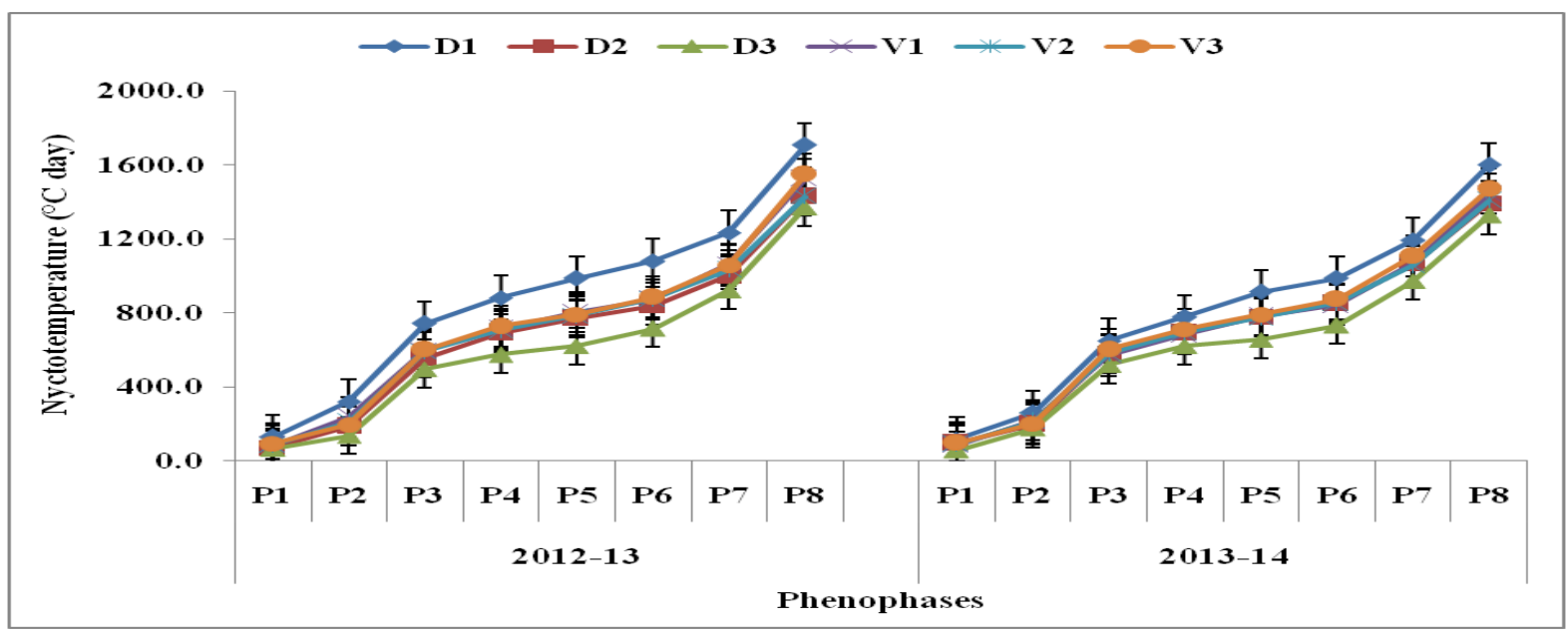

Fig.6 Effect of growing environments and varieties on thermal use efficiency $\left(\mathrm{g} / \mathrm{m}^{2}{ }^{\circ} \mathrm{C}\right.$ day) in mustard at various growth intervals during 2012-13 and 2013-14

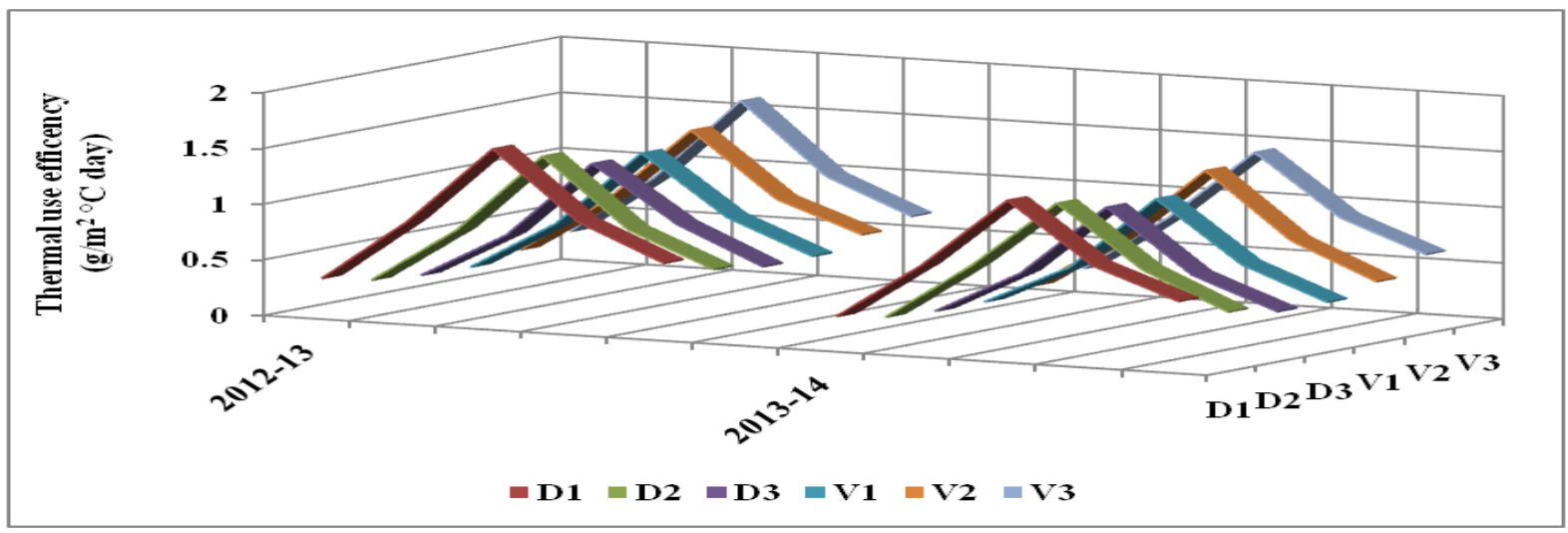



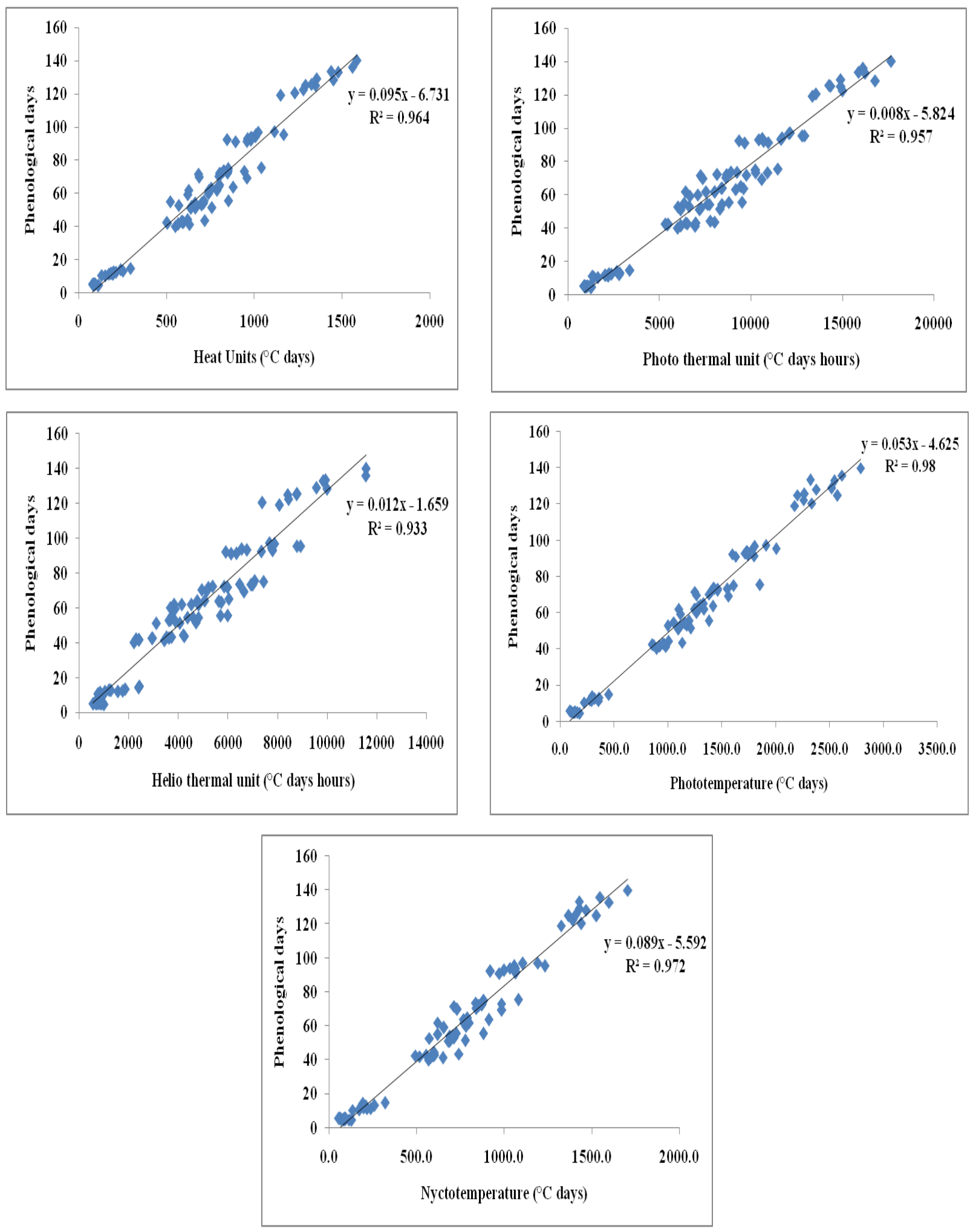

Fig.7 Regression between mustard phenology and (a) heat units $\left({ }^{\circ} \mathrm{C}\right.$ day); (b) photo-thermal units $\left({ }^{\circ} \mathrm{C}\right.$ day hours); (c) helio-thermal units $\left({ }^{\circ} \mathrm{C}\right.$ day hours); (d) phototemperature $\left({ }^{\circ} \mathrm{C}\right.$ day); (e) nyctotemperature $\left({ }^{\circ} \mathrm{C}\right.$ day $)$ 

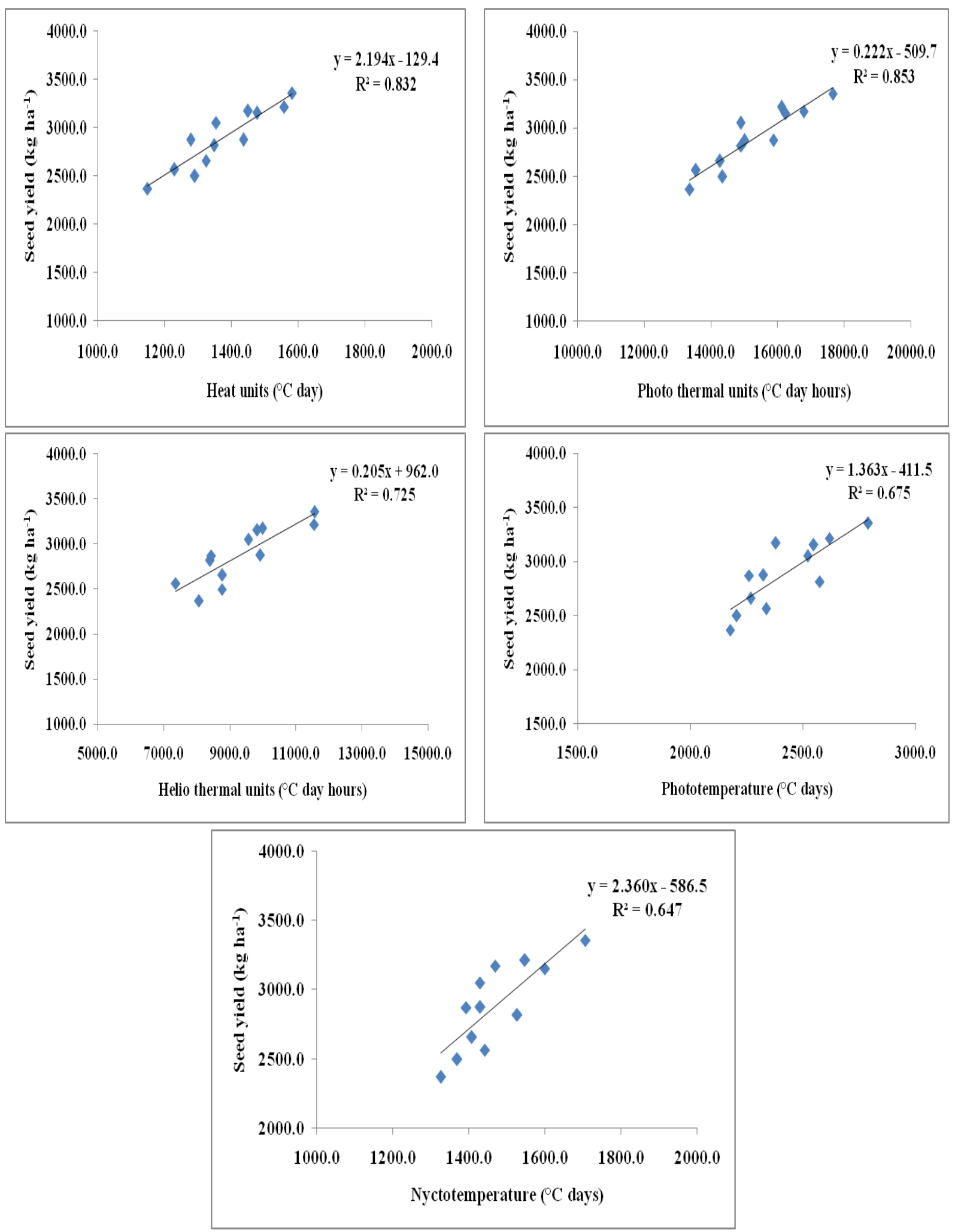

Fig.8 Regression between mustard seed yield and (a) heat units $\left({ }^{\circ} \mathrm{C}\right.$ day); (b) photo-thermal units $\left({ }^{\circ} \mathrm{C}\right.$ day hours); (c) helio-thermal units $\left({ }^{\circ} \mathrm{C}\right.$ day hours); (d) phototemperature $\left({ }^{\circ} \mathrm{C}\right.$ day); (e) nyctotemperature $\left({ }^{\circ} \mathrm{C}\right.$ day) 
Table.1 Correlation coefficient between seed and biological yield of mustard with temperature based agrometeorological indices

\begin{tabular}{|c|c|c|}
\hline Agrometeorological Indices & Seed yield (kg ha $\left.{ }^{-1}\right)$ & Biological yield $\left(\mathrm{g} \mathrm{m}^{-2}\right)$ \\
\hline HU ( ${ }^{\circ} \mathrm{C}$ day $)$ & $0.912 * *$ & $0.973 * *$ \\
\hline PTU $\left({ }^{\circ} \mathrm{C}\right.$ day hours $)$ & $0.924 * *$ & $0.938 * *$ \\
\hline HTU $\left({ }^{\circ} \mathrm{C}\right.$ day hours $)$ & $0.851 * *$ & $0.973 * *$ \\
\hline $\mathbf{T}_{\mathbf{p}}\left({ }^{\circ} \mathbf{C}\right.$ day $)$ & $0.797 * *$ & $0.748 * *$ \\
\hline $\mathbf{T}_{\mathbf{n}}\left({ }^{\circ} \mathbf{C}\right.$ day $)$ & $0.805 * *$ & $0.769 * *$ \\
\hline
\end{tabular}

\section{Thermal Use Efficiency (TUE)}

The quantification of thermal use efficiency (the amount of dry matter produced per unit of growing degree day) is important for determination of yield potential in different environments. TUE during 2013-14 crop season was lower than that of 2012-13 (Fig. $6)$. The delay in sowing of the crop due to abnormal weather conditions which led to poor growth and yield parameters during 2013-14 may have resulted in lower TUE. The TUE was highest at 90 days after sowing (end of seed filling - $\mathrm{P}_{7}$ ) during both the crop seasons and lowest at 30 days after sowing (early vegetative stage $-\mathrm{P}_{3}$ ). Delayed sowing led to significant drop of TUE in both crop seasons due to decreased biomass production and shortening of crop growing period resulting in lesser accumulation of $\mathrm{HU}$. Among the varieties, the TUE was higher in RH $0749\left(V_{3}\right)$ followed by Laxmi $\left(V_{2}\right)$ and minimum in RH $30\left(\mathrm{~V}_{1}\right)$ during both the crop seasons. These findings are in close agreement with those reported by Roy et al., (2005); Neogi et al., (2005); Singh and Singh (2005); Singh et al., (2014) and Kingra and Kaur (2012).

\section{Regression analysis between agrometeorological indices and mustard phenology, seed and biological yield}

The crop sown with $\mathrm{D}_{1}$ sowing date accumulated higher values for all temperature based agrometeorological indices to attain various phenological stages in comparison with later two sowings. Sowing time influences phenological development of crop plants through temperature related agrometeorological indices. Sowing at optimum time gives higher yields due to suitable environment that prevail at all the growth stages (Shekhawat et al., 2012).

Very high values of coefficients of determination $\left(\mathrm{R}^{2}\right)$ between the agormeteorological indices; and the mustard phenology, seed yield and biological yield indicated that the occurrence of various phenophases can very accurately be predicted using these agormeteorological indices (Fig. 7, 8 and Table 1). These results are in conformity with the findings of Khushu et al., (2008) and Singh et al., (2013).

The optimum values of agrometeorological indices were required for attaining maturity and higher yield under early sown crop. Among varieties above mention agro meteorological indices were more with variety RH 0749 as compared to Laxmi and RH 30 respectively. The higher agro meteorological indices with variety RH 0749 might be due to higher seed yield. Strong positive relationship was also observed which signifies the importance of temperature based agrometeorological indices. From the study, it can be concluded that there is a necessity of management and applications of these indices 
in order to allocate inter-comparison of the significant results and to improve the understanding.

\section{Acknowledgement}

The authors thank to Department of Agricultural Meteorology, Chaudhary Charan Singh Haryana Agricultural University, Hisar, India, for providing necessary support for conducting the research. The authors also thank the INSPIRE program, Department of Science and Technology, Ministry of science and Technology, India for financial support as $\mathrm{PhD}$ fellowship to the corresponding author.

\section{References}

Anonymous: Stastical Abstract of Haryana of different years.http://esaharyana.gov.in/ Data/StateStatisticalAbstract/Statistical Abstract.pdf 2015.

Dalezios, N. R., A. Loukas, and D. Bampzelis: Assessment of NDVI and agrometeorological indices for major crops in central Greece. Phy. Chem. Earth., 27: 1025-1029 2002.

Goswami B, G. S. Mahi, and U. S. Saikia: Effect of few important climatic factors on phenology, growth and yield of rice and wheat. J. Agromet., 27: 223-228 2006.

Khushu, M. K., Naseer-Ur- Rahman, M. Singh, A. K. Tiku, and A. S. Bali: Thermal time indices for some mustard genotypes in the Jammu region. $J$. Agromet. 10(2): 224-227 2008.

Kingra, P. K. and P. Kaur: Effect of Dates of Sowing on Thermal Utilisation and Heat Use Efficiency of Groundnut Cultivars in Central Punjab. J. Agril. Phy., 12(1): 54-62 2012.

Kumar, A.: Rapeseed-mustard in India: current status and future prospects. In: Winter School on Advances in Rapeseed-Mustard Research
Technology for Sustainable Production of Oilseeds, National Centre on Rapeseed-Mustard, Sewar, Bharatpur, December 15 to January 04, 2005, pp. 278-288 2005.

Kumar, G., N. V. K. Chakravarty, R. S. Kurothe, D. R. Sena, K. P. Tripathi, T. Adak, D. Haldar, and Anuranjan: Effect of projected climate change on mustard (Brassica juncea). J. Agromet., 12(2): 168-173 2010.

McMaster, G. S., W. W. Wilhelm: Growing degree days: One equation, two interpretations. Agril. For. Meteor., 87: 291-300. doi: 10.1016/S01681923(97)00027-0 1997.

Morrison, J. I. L.: Global environmental change impacts on crop growth and production in Europe. Implications of global environmental change for crops in Europe. Asp. Appl. Biol., 45: 62-74 1996.

Neogi, P., N. V. K. Chakravarty, A. K. Srivastava, B. Goutom, R. K. Katiyar, and H. B. Singh: Thermal time and its relationship with seed yield and oil productivity in Brassica cultivars. Int. J. Brassica, 7(1 \& 2): 63-70 2005.

Parya, M., S. K. Dutta, S. Jena, R. Nath, and P. K. Chakraborty: Effect of thermal stress on wheat productivity in West Bengal. J. Agromet., 12: 217-20 2010.

Qiao-yan, L. I., Y. I. N. Jun, Wan-dai Liu, Mei Zhou, L. I. Lei, Ji-shan Niu, Hongbin Niu, M. A. Ying: Determination of optimum growing degree days (GDD) range before winter for wheat cultivars with different growth characteristics in North China Plain. Journal of Integrative Agriculture, 11:405-415. doi: $\quad 10.1016 /$ S2095-3119(12)60025-2 2012.

Renganayaki, P. R. and V. Krishnasamy: Correlation equation for synchronized flowering in sunflower (Helianthus annuus L.) hybrid KBSH-1 parental 
lines based on meteorological parameters. Afric. J. Agril. Res., 8(17):1738-1742 2013.

Roy, S., R. L. Meena, S. C. Sharma, K. Vinod, C. Chattopadhyay, S. A. Khan, and N. V. K. Chakravarthy,: Thermal requirement of oilseed Brassica cultivars at different phonological stages under varying environmental conditions. Ind. J. Agril. Sci., 75(11): 17-21 2005.

Shekhawat, K., S. S. Rathore, O. P. Premi, B. K. Kandpal, and J. S. Chauhan: Advances in agronomic management of Indian mustard (Brassica juncea (L.) Czernj. Cosson): An Overview, Inter. J. Agron. Volume 2012 (2012), pages, 2012. doi:10.1155/2012/408284 2012.

Si, P. and G. H. Walton: Determination of oil concentration and seed yield in canola and Indian mustard in the lower rainfall areas of Western Australia. Aust. J. Agril. Res., 55(3): 367-377 2004.

Singh, A., R. Avtar, D. Singh, O. Sangwan, and P. Balyan: Genetic variability, character association and path analysis for seed yield and component traits under two environments in Indian mustard. J. Oilse. Bra., 4(1), 43-48 2013.

Singh, M.P., Lallu and N.B. Singh: Thermal requirement of Indian mustard (Brassica juncea) at different phenological stages under late sown condition. Ind. J. Pl. Physiol., 19(3): 238-243 2014.

Singh, R. and S. Singh: Wheat yield variability in relation with weather parameters. Haryana Agric. Univ. J. Res., 35: 23-26 2005.

Srivastava A. K., N. V. K. Chakravarty, T. Adak: Quantification of growth and yield of oilseed Brassica using thermal indices under semi-arid environment. $J$. Agromet., 13(2): 135-140 2011.

Warthinhton, C. M., and C. M. Hatchinson: Accumulated degree days as a model to determine key development stages and evacuate yield and quality of potato in Northeast Florida. Proceeding of State Horticulture Society, 118: 98-101 2005.

\section{How to cite this article:}

Divesh Choudhary, Raj Singh, C.. Dagar, Anil Kumar and Surender Singh. 2018. Temperature Based Agrometeorological Indices for Indian Mustard under Different Growing Environments in Western Haryana, India. Int.J.Curr.Microbiol.App.Sci. 7(01): 1025-1035. doi: https://doi.org/10.20546/ijcmas.2018.701.123 